\title{
ANALISIS MOMEN NOMINAL ULTIMIT TIANG BOR UNTUK DIGUNAKAN PADA PERHITUNGAN METODE BROMS
}

\author{
Reynard Julio Widjaja ${ }^{1}$ dan Gregorius Sandjaja Sentosa ${ }^{2}$ \\ ${ }^{1}$ Program Studi Sarjana Teknik Sipil, Universitas Tarumanagara, Jl. Letjen S. Parman No.1 Jakarta \\ reynard.julio7@gmail.com \\ ${ }^{2}$ Program Studi Sarjana Teknik Sipil, Universitas Tarumanagara, Jl. Letjen S. Parman No.1 Jakarta \\ gregoriuss@ft.untar.ac.id
}

Masuk: 17-01-2020, revisi: 05-05-2020, diterima untuk diterbitkan: 13-05-2020

\begin{abstract}
Foundation is the lowest part of construction that is important to bear the burden of the building above it. In this analysis, used the calculation of circle cross section analysis to get the nominal moment that can be hold to bore piled that have a diameter $30 \mathrm{~cm}$ to $100 \mathrm{~cm}$, other than that used the different of concrete quality, concrete quality that used in this analysis is $22.5 \mathrm{MPa}, 25 \mathrm{MPa}$, and $30 \mathrm{MPa}$. The amount of reinforcement used is also different, such as 4 reinforcement, 6 reinforcement and 8 reinforcement. The reduction factor that used is the conservative number which is 0.65. After obtained the value of ultimate moment, used the Broms chart to get the value of Hu and H. From the calculation, the result between $50 \mathrm{kNm}$ to $2244 \mathrm{kNm}$. Based on the comparison with Pile Foundation from brochure, ultimate moment of the Pile Foundation is stronger than the ultimate moment of the bored pile eith $340 \mathrm{kNm}$ for pile foundation dan $206 \mathrm{kNm}$ for bored pile.
\end{abstract}

Keywords: Ultimate Moment; Bored pile; Broms chart; Circle Cross Section.

\begin{abstract}
ABSTRAK
Fondasi merupakan bagian paling bawah dari suatu konstruksi yang penting untuk memikul beban bangunan di atasnya. Dalam analisis ini digunakan perhitungan analisis penampang lingkaran yang berguna untuk mencari momen nominal yang dapat ditahan oleh tiang bor yang memiliki diameter $30 \mathrm{~cm}$ sampai $100 \mathrm{~cm}$, selain itu digunakan juga mutu beton yang berbeda, mutu beton yang dipakai dalam analisis ini adalah mutu beton fc' 22.5 $\mathrm{MPa}$, fc' $25 \mathrm{MPa}$, dan fc' $30 \mathrm{MPa}$. Jumlah tulangan yang dipakai pun juga berbeda yaitu 4 tulangan, 6 tulangan dan 8 tulangan. Untuk faktor reduksi kekuatan sendiri angka yang diambil adalah angka yang konservatif yaitu 0.65 agar lebih aman. Dari hasil perhitungan, momen ultimit diperoleh antara $50 \mathrm{kNm}$ sampai $2244 \mathrm{kNm}$. Setelah didapat nilai momen ultimit, momen dimasukkan ke dalam grafik Broms agar mendapatkan nilai Hu dan Hijin. Berdasarkan hasil perbandingan dengan tiang pancang yang didapat dari brosur, momen ultimit tiang pancang lebih kuat daripada momen ultimit dari tiang bor dengan momen $340 \mathrm{kNm}$ untuk tiang pancang dan $206 \mathrm{kNm}$ untuk tiang bor.
\end{abstract}

Kata Kunci: Momen Ultimit; Tiang bor; Grafik Broms; Analisis Penampang Lingkaran.

\section{PENDAHULUAN}

Fondasi merupakan tahap awal dalam membangun sebuah bangunan. Fondasi berasal dari kata foundation, dalam bahasa keseharian masyarakat Indonesia pada umumnya menggukan kata fondasi atau lebih sering disebut pondasi. Menurut Kamus Besar Bahasa Indonesia (2008:414) yang menyatakan bahwa fondasi merupakan dasar bangunan yang kuat dan biasanya terletak di bawah permukaan tanah tempat bangunan didirikan. Fondasi tiang bor berinteraksi dengan tanah untuk menghasilkan daya dukung yang mampu memikul dan memberikan keamanan pada struktur atas. Untuk menghasilkan daya dukung yang akurat maka diperlukan suatu penyelidikan tanah yang akurat juga, selain itu juga harus menghitung nilai momen ultimit yang terjadi dengan metode analisa penampang. Analisis penampang terhadap lentur dimaksudkan untuk menghitung kapasitas momen nominal penampang beton bertulang. Analisis dilakukan dengan pendekatan blok tegangan persegi ekivalen, dengan distribusi tegangan tekan beton dan regangan beton diasumsikan berbentuk persegi (Ridwan, 2012). Analisis penampang bertujuan untuk mengetahui kapasitas penampang (momen nominal), dengan demikian harus diberikan data mengenai dimensi penampang dan tulangannya. Tujuan penelitian ini adalah membandingkan nilai momen ultimit yang didapat dari penampang lingkaran, selain itu membuat grafik diagram yang didapat dari hasil perhitungan dan memudahkan orang untuk mendapat momen ultimit penampang tiang bor. 


\section{Fondasi tiang bor}

Fondasi tiang bor adalah fondasi tiang yang pemasangannya dilakukan dengan mengebor tanah lebih dahulu (Hardiyatmo, 2010). Pemasangan fondasi tiang bor ke dalam tanah dilakukan dengan cara mengebor tanah terlebih dahulu, yang kemudian diisi tulangan yang telah dirangkai dan dicor beton. Apabila tanah mengandung air, maka dibutuhkan pipa besi atau yang biasa disebut dengan temporary casing untuk menahan dinding lubang agar tidak terjadi kelongsoran, dan pipa ini akan dikeluarkan pada waktu pengecoran beton.

\section{Analisis penampang}

Dalam praktek, sistem tulangan tunggal hampir tidak pernah dimanfaatkan untuk balok, karena pemasangan batang tulangan tambahan di daerah tekan akan mempermudah pengaitan Sengkang (Wahyudi \& Rahim, 1997). Tujuan tulangan tekan ini diperlukan untuk:

1. Meningkatkan momen penahanan penampang karena dimensi penampang yang terbatas.

2. Meningkatkan kapasitas rotasi penampang yang berkaitan dengan peningkatkan daktilitas penampang.

3. Meningkatkan kekakuan penampang, sehingga dapat mengurangi lendutan pada struktur.

4. Dapat mengantisipasi kemungkinan adanya momen yang berubah tanda.

\section{Momen nominal penampang persegi}

Dalam proses desain suatu balok beton bertulang dengan metode kekuatan (Strength Design Method) atau yang dikenal pula dengan metode ultimit, mengambil beberapa asumsi sebagai berikut:

1. Regangan yang terjadi pada beton dan tulangan baja adalah sama.

2. Regangan yang terjadi pada beton berbanding lurus terhadap jaraknya ke sumbu netral penampang.

3. Modulus Elastisitas, Es $=200.000 \mathrm{MPa}$, dan tegangan yang timbul pada tulangan baja dalam daerah elastis sama dengan nilai regangan dikalikan dengan Es.

4. Penampang datar akan tetap datar setelah terjadi lentur.

5. Kuat tarik dari beton diabaikan.

6. Pada kondisi keruntuhan regangan maksimum yang terjadi pada serat tekan beton terluar, besarnya adalah sama dengan Ecu $=0,003$.

7. Untuk perhitungan kuat rencana, bentuk dari distribusi tegangan tekan beton diasumsikan berupa persegi empat, sesuai dengan asumsi dalam SNI 2847:2013 pasal 10.2.

Kuat nominal dari suatu komponen struktur (baik yang memikul lentur, beban aksial, geser maupun puntir), yang dihitung berdasarkan kaidah-kaidah yang berlaku, harus dikalikan dengan suatu faktor reduksi yang besarnya kurang dari satu. Dalam SNI 2847:2013, pasal 9.3 digunakan beberapa nilai faktor reduksi kekuatan, $\phi$, sebagai berikut:

- untuk penampang dominan tarik $\phi=0,90$.

- untuk penampang dominan tekan dengan tulangan spiral $\phi=0,75$ tulangan non-spiral $\phi=0,65$.

- untuk geser dan puntir $\phi=0,75$.

- untuk tumpu pada beton $\phi=0,65$.

Menurut SNI 2847:2013, luas pada tulangan struktur komponen tekan tidak boleh kurang dari 0,01 Ag atau lebih dari 0,08 Ag. Penampang Tulangan Tunggal pada Balok Persegi suatu balok dinyatakan bertulangan tunggal jika pada penampang beton bertulang tersebut hanya diperhitungkan terpasang baja tulangan pada satu sisi saja, yaitu pada bagian serat yang menerima gaya tarik seperti yang ditunjukan pada gambar 1:

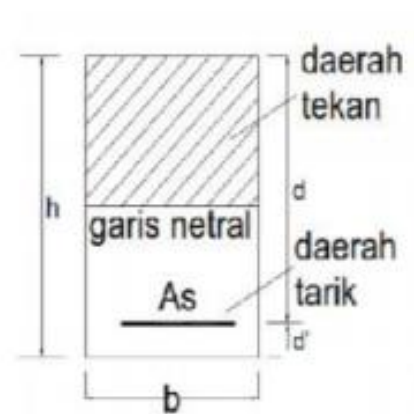

(a)

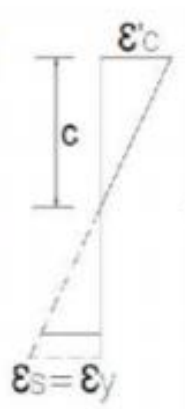

(b)

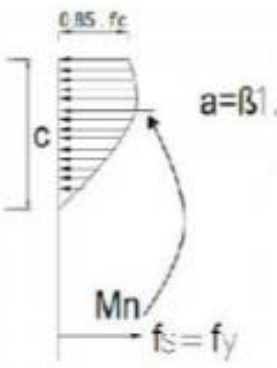

(c)

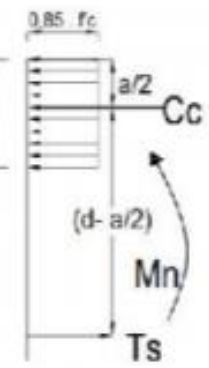

(d)

Gambar 1. Distribusi tegangan dan regangan pada penampang balok (a) Penampang Melintang Balok; (b) Distribusi Regangan; (c) Distribusi Tegangan; (d) Distribusi Tegangan Tekan Persegi Ekuivalen

(Sumber: Disain Beton Bertulang Jilid 1, Chu Kia Wang) 


\section{Momen nominal penampang lingkaran}

Berikut merupakan cara perhitungan untuk Analisis Penampang Lingkaran:

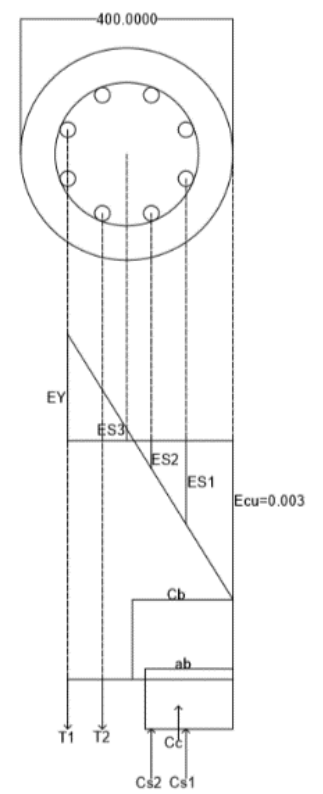

Gambar 2. Analisis Penampang Lingkaran (Sumber: Setiawan, 2017)

Berikut uraian cara perhitungan yang diambil dari buku Agus setiawan . 2017:

1. Karena tulangan memanjang disusun secara simetris terhadap sumbu A-A melalui pusat lingkaran, maka pusat berat plastis pun terletak pada sumbu tersebut.

2. Tentukan lokasi sumbu netral

$$
\begin{array}{r}
\frac{C b}{d}=\frac{0.003}{0.003+E y}=\frac{600}{600+f y} \\
a b=0.85(\mathrm{Cb})
\end{array}
$$

3. Hitung properti segmen lingkaran

Luas segmen $=r^{2}(\alpha-\sin \alpha \cos \alpha)$

Lokasi titik berat $\mathrm{X}$ dari pusat lingkaran:

$$
X=\frac{2}{3} \frac{r \sin ^{3} \alpha}{\alpha-\sin \alpha \cos \alpha}
$$

$$
\begin{aligned}
& \mathrm{r} \cos \alpha=\mathrm{r}-\alpha \quad \text { atau } \quad \cos \alpha=\left(1-\frac{\mathrm{a}}{\mathrm{r}}\right) \\
& \mathrm{Z}=\mathrm{r}-\mathrm{X}
\end{aligned}
$$

4. Hitung gaya tekan Cc:

$\mathrm{Cc}=0.85 \mathrm{fc}$ ' $\mathrm{x}$ luas segmen lingkaran

Hitung regangan, tegangan dan gaya pada tulangan tarik dan tekan. Regangan pada tulangan dihitung dengan menggunakan diagram regangan.

Untuk T1:

$$
\begin{aligned}
& \mathrm{E}=\mathrm{Ey}=f y / E s \\
& \mathrm{~T} 1=2(\mathrm{As})(\mathrm{fy})
\end{aligned}
$$

Untuk T2:

$$
\begin{aligned}
& \mathrm{Es} 3=\frac{\mathrm{s} 2+(\mathrm{s} 2-\mathrm{S} 3)}{(\mathrm{d}-\mathrm{cb})} \times \mathrm{Ey} \\
& \mathrm{fs} 3=\mathrm{Es} 3 \times \mathrm{E}
\end{aligned}
$$


Untuk Cs1:

$$
\mathrm{T} 2=\mathrm{fs} 3 \times 2(\mathrm{As})
$$

$$
\begin{gathered}
\mathrm{Es} 1=\frac{\mathrm{s} 4}{\mathrm{Cb}} \mathrm{Ecu} \\
\mathrm{fs} 1=\mathrm{Es} 1 \times \mathrm{E} \\
\mathrm{Cs} 1=2(\mathrm{As})\left(\mathrm{fs} 1-0.85\left(\mathrm{fc}^{\prime}\right)\right)
\end{gathered}
$$

Untuk Cs2:

$$
\begin{gathered}
\mathrm{Es} 2=\frac{\mathrm{S} 3}{\mathrm{Cb}} \mathrm{Ecu} \\
\mathrm{fs} 2=\mathrm{Es} 2 \times \mathrm{Es} \\
\mathrm{Cs} 2=2(\mathrm{As})\left(\mathrm{fs} 2-0.85\left(\mathrm{fc}^{\prime}\right)\right)
\end{gathered}
$$

Tegangan pada tulangan tekan dikurangi sebesar $0.85 \mathrm{fc}$ untuk memperhitungkan bagian beton yang ditempati oleh tulangan baja

5. Gaya tekan pada kondisi seimbang, $\mathrm{Pb}$ dihitung sebagai berikut:

$$
\mathrm{Pb}=\mathrm{Cc}+\sum \mathrm{Cs}-\sum \mathrm{T}
$$

Untuk penampang dalam kondisi seimbang, E1 $=0.002$, dan $\theta=0.65$, sehingga:

$$
\theta \mathrm{Pb}=0.65(\mathrm{~Pb})
$$

6. Hitung jumlahan momen terhadap pusat berat plastis (sumbu A-A), untuk mendapatkan nilai Mb, maka:

$$
\begin{gathered}
\mathrm{Mb}=\mathrm{Cc} . \mathrm{X}+\mathrm{Cs} 1 \times \mathrm{S} 1+\mathrm{Cs} 2 \times \mathrm{S} 2+\mathrm{T} 1 \times \mathrm{S} 1+\mathrm{T} 2 \times \mathrm{S} 2 \\
\theta \mathrm{Mb}=0.65(\mathrm{Mb})
\end{gathered}
$$

7. Tentukan nilai eksentrisitas pada kondisi seimbang:

$$
E b=\frac{M b}{P b}
$$

8. Perhatikan bahwa nilai $\theta$ dapat ditingkatkan menjadi 0.75 apabila sengkang yang dipakai adalah sengkang spiral.

Cara analisis penampang kolom, dilakukan dengan menerapkan prinsip - prinsip kesetimbangan gaya pada ilmu statika. Untuk keperluan desain awal terdapat diagram - diagram atau tabel yang dapat digunakan untuk menentukan ukuran atau kebutuhan tulangan yang diperlukan untuk memikul beban Pu dan momen Mu. Gambar 3 menunjukkan contoh diagram interaksi yang dapat digunakan untuk keperluan desain kolom, diagram ini dihasilkan oleh ACI.

Untuk persamaan dalam pendekatan empiris dalam mencari dimensi penampang kolom bulat, baik hancur tekan maupun tarik (Dipohusodo, 1993).

-Persamaan untuk penampang bulat dengan hancur tarik menentukan:

$$
\mathrm{Pn}=0.85 \mathrm{fc} \mathrm{c}^{2}\left(\sqrt{\left.\frac{0.85 e b}{h}-0.38\right)^{2}+\frac{\rho g m D s}{2.5 h}}-\left(\frac{0.85 e b}{h}-0.38\right)\right.
$$

-Persamaan untuk penampang bulat dengan hancur tekan menentukan:

$$
\operatorname{Pn}=\frac{A s . f y}{\frac{3 e}{D s}+1.0}+\frac{A g . f c^{\prime}}{\frac{9.6 h e}{(0.8 h+0.67 D s)^{2}+1.18}}
$$

dengan $\mathrm{h}=$ diameter penampang, $\mathrm{Ds}=$ diameter lingkaran tulangan terjauh dari sumbu, $\mathrm{e}=$ eksentrisitas terhadap pusat plastis penampang,

$$
\rho g=\frac{A s t}{A g}
$$

dengan Ast = luas penampang total, Ag = luas penampang bruto

Metode Broms (Tomlinson, 1984) dapat digunakan untuk menghitung tahanan maksimum akibat gaya lateral baik rigid piles maupun long piles yang berada pada lapisan tanah homogen dan murni berupa tanah kohesif atau granuler. 


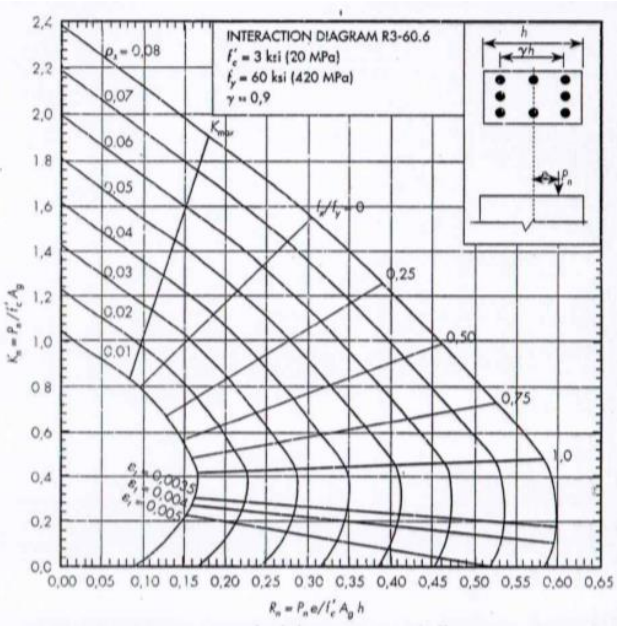

Gambar 3. Diagram interaksi kolom persegi untuk fc' $=27.5 \mathrm{Mpa}$, fy $=420 \mathrm{Mpa}$, dan $\gamma=0.9$

(Sumber: ACI Design Handbook, Vol. 2, Columns.)

\section{METODOLOGI PENELITIAN}

Berikut metodologi dan diagram alir dalam penyusunan:

1. Perhitungan Analisa Penampang

Perhitungan Analisa penampang dengan menggunakan analisis penampang lingkaran yang bertujuan untuk mendapatkan nilai momen nominal ultimit untuk tiang bor.

2. Mutu beton yang berbeda

Mendapatkan nilai momen nominal dari mutu yang berbeda yaitu f'c 20Mpa, 25Mpa dan $30 \mathrm{Mpa}$.

3. Perhitungan dengan aplikasi

Aplikasi yang dipakai di computer untuk membantu mencari nilai momen nominal dari penampang.

4. Analisis dan Pembahasan

Hasil dari perhitungan akan disajikan dalam bentuk grafik, untuk mengetahui nilai momen nominal.

5. Kesimpulan

Berdasarkan hasil analisis data dibuat kesimpulan

Berikut merupakan diagram alir:

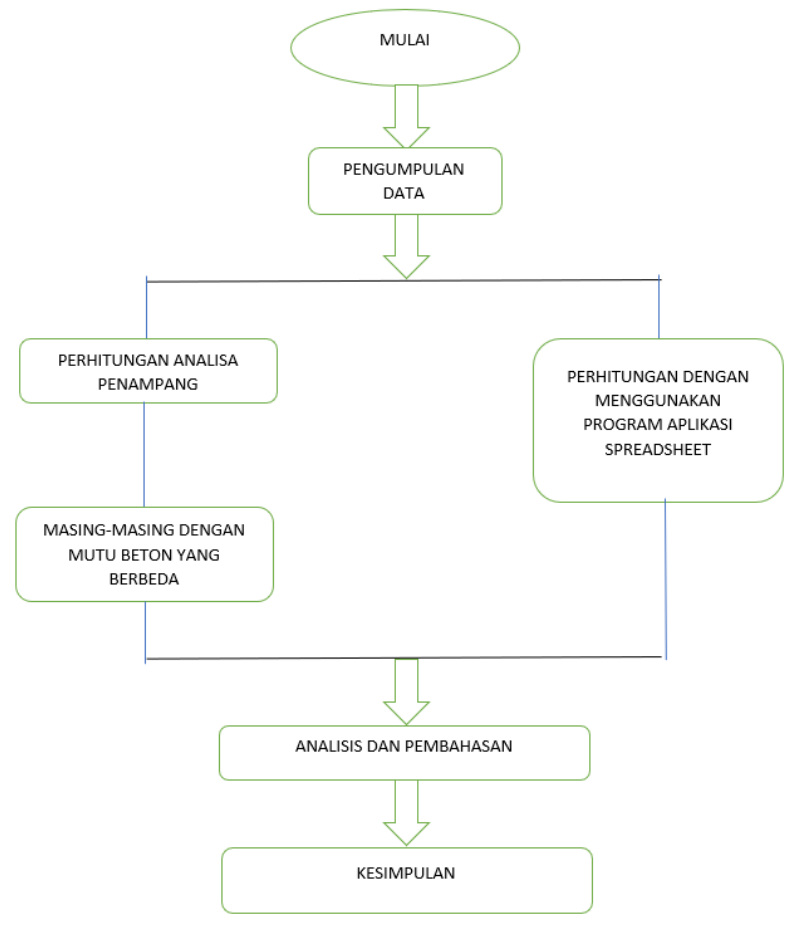

Gambar 4. Diagram alir metode penelitian 


\section{ANALISIS DAN PEMBAHASAN}

Analisis terhadap momen nominal dan ultimit penampang tiang bor diameter $500 \mathrm{~mm}$ dan fc 22.5 dengan uraian sebagai berikut:

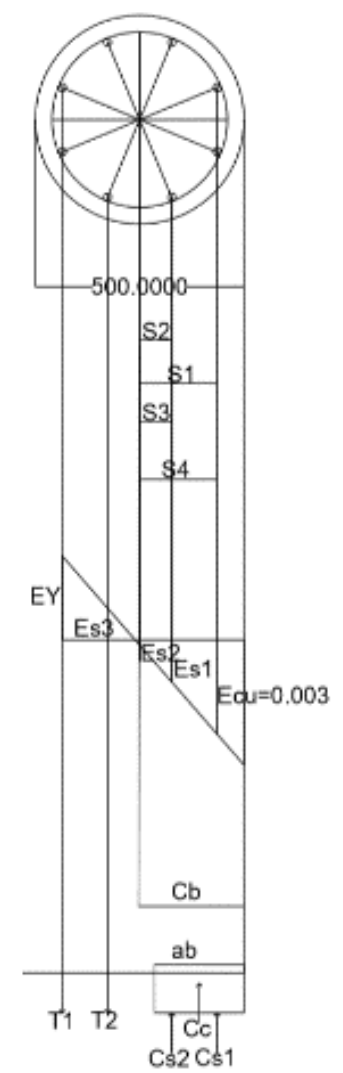

Gambar 5. Analisa penampang lingkaran fc' $22.5 \mathrm{Mpa}$, diameter $500 \mathrm{~mm}$

$\mathrm{S}=185 \mathrm{~mm}$

$\mathrm{S} 1=185.2378 \mathrm{~mm}$

$\mathrm{S} 2=76.7280 \mathrm{~mm}$

$\mathrm{d}=250+\mathrm{S} 1=435.2378 \mathrm{~mm}$

$\mathrm{S} 3=85.6881 \mathrm{~mm}$

$\mathrm{S} 4=194.4765 \mathrm{~mm}$

1. Tentukan lokasi sumbu netral

$\mathrm{d}=435.2578 \mathrm{~mm}$

$\frac{\mathrm{cb}}{\mathrm{d}}=\frac{0.003}{0.003+\mathrm{Ey}}=\frac{600}{600+\mathrm{fy}}$

$\mathrm{cb}=\frac{600}{600+400}(435.2378)=261.14268 \mathrm{~mm}$

$\mathrm{ab}=0.85(261.14268)=221.971278 \mathrm{~mm}$

2. Hitung 460ias460460ty segmen lingkaran

Luas segmen $=r^{2}(\alpha-\sin \alpha \cos \alpha)$

Lokasi titik berat $\mathrm{X}$ dari pusat lingkaran:

$\mathrm{X}=\frac{2}{3} \frac{\mathrm{r} \sin ^{3} \alpha}{\alpha-\sin \alpha \cos \alpha}$

$\mathrm{r} \cos \alpha=\mathrm{r}-\alpha \quad$ atau $\quad \cos \alpha=\left(1-\frac{\mathrm{a}}{\mathrm{r}}\right)$

$\cos \alpha=\left(1-\frac{221.971278}{250}\right)=0.112330888$

Maka $\alpha=83.55030144=1.45822781 \mathrm{rad}$

$\sin \alpha=0.993685$

Luas segmen $=250^{2}(1.45822781-0.993685(0.112330888))$

$$
=84162.89322 \mathrm{~mm}^{2}
$$




$$
\begin{aligned}
& X=\frac{2}{3} \frac{250(0.993685)^{3}}{(1.45822781-(0.993685 \times 0.112330888))}=121.4221017 \mathrm{~mm} \\
& Z=r-X=250-121.4221017=128.5778983 \mathrm{~mm}
\end{aligned}
$$

3. Hitung gaya tekan Cc:

$\mathrm{Cc}=0.85 \mathrm{fc} \times$ luas segmen lingkaran

$=0.85(22.5)(84162.89322)=1609615.333 \mathrm{~N}$

Gaya ini bekerja sejarak $121.4221017 \mathrm{~mm}$ dari pusat lingkaran.

Hitung regangan, tegangan dan gaya pada tulangan tarik dan tekan. Regangan pada tulangan dihitung dengan menggunakan diagram regangan.

Untuk T1:

$$
\begin{aligned}
& E=E y=f y / E s=400 / 200000=0.002 \\
& f s=f y=400 \mathrm{Mpa} \\
& T 1=2(283.8257)(500)=226822.99 \mathrm{~N}
\end{aligned}
$$

Untuk T2:

$$
\begin{aligned}
& \mathrm{Es} 3=\frac{67.7679}{171.0951} \mathrm{Ey}=\frac{67.7679}{171.0951}(0.002)=0.000779 \\
& \mathrm{fs} 3=0.000779 \times 200000=155.8 \mathrm{Mpa} \\
& \mathrm{T} 2=155.8 \times 2(283.5287)=88347.54292 \mathrm{~N}
\end{aligned}
$$

Untuk Cs1:

$$
\begin{aligned}
& \mathrm{Es} 1=\frac{\mathrm{s} 4}{\mathrm{Cb}} \mathrm{Ecu}=\frac{194.4765}{261.1427}(0.003)=0.002234 \\
& \mathrm{fs} 1=0.002234 \times 200000=446.8 \mathrm{Mpa} \\
& \mathrm{Cs} 1=2(283.5287)(446.8-0.85(22.5))=242516.2735 \mathrm{~N}
\end{aligned}
$$

Untuk Cs2:

$$
\begin{aligned}
& \mathrm{Es} 2=\frac{\mathrm{s} 3}{\mathrm{Cb}} \mathrm{Ecu}=\frac{83.6881}{261.1427}(0.003)=0.0009614 \\
& \mathrm{fs} 2=0.0009614 \times 200000=192.28 \mathrm{Mpa} \\
& \mathrm{Cs} 2=2(283.5287)(192.28-0.85(22.5))=98188.8241 \mathrm{~N}
\end{aligned}
$$

4. Gaya tekan pada kondisi seimbang, $\mathrm{Pb}$ dihitung sebagai berikut:

$$
\begin{aligned}
\mathrm{Pb} & =\mathrm{Cc}+\sum \mathrm{Cs}-\sum \mathrm{T} \\
& =1609615.333+(242516.2735+98188.8241)-(226822.99+88347.54292) \\
& =1635149.898 \mathrm{~N}
\end{aligned}
$$

Untuk penampang dalam kondisi seimbang, $\mathrm{E} 1=0.002$, dan $\theta=0.65$, sehingga:

$$
\theta \mathrm{Pb}=0,65(1635149.898)=1062847.433 \mathrm{~N}=1062.847433 \mathrm{kN}
$$

5. Hitung jumlahan momen terhadap pusat berat plastis (sumbu A-A), untuk mendapatkan nilai Mb, maka:

$\mathrm{Mb}=\mathrm{Cc} . \mathrm{X}+\mathrm{Cs} 1 \times \mathrm{S} 1+\mathrm{Cs} 2 \times \mathrm{S} 2+\mathrm{T} 1 \times \mathrm{S} 1+\mathrm{T} 2 \times \mathrm{S} 2$

$$
\begin{aligned}
= & 1609615.333(121.4221017)+242516.2735(185.2378)+98188.8241(76.7280)+226822.99 \\
& (185.2378)+88347.54292(70.7995) \\
= & 296171043.2 \mathrm{Nmm} \\
\theta \mathrm{Mb}= & 0.65(296171043.2)=192511178.1 \mathrm{Nmm}=192.5111781 \mathrm{kNm}
\end{aligned}
$$

6. Tentukan nilai eksentrisitas pada kondisi seimbang:

$$
\mathrm{Eb}=\frac{\mathrm{Mb}}{\mathrm{Pb}}=\frac{296171043.2}{1635149.898}=181.127763 \mathrm{~mm}
$$

Dari hasil perhitungan, maka didapatkan:

Tabel 1. Perhitungan momen ultimit, jumlah tulangan 8 , f'c $22.5 \mathrm{Mpa}$

\begin{tabular}{cccccc}
\hline $\begin{array}{c}\text { Diameter } \\
(\mathrm{mm})\end{array}$ & $\begin{array}{c}\text { Luas Penampang } \\
\left(\mathrm{mm}^{\wedge} 2\right)\end{array}$ & $\begin{array}{c}0.01 \mathrm{Ag} \\
\left(\mathrm{mm}^{\wedge} 2\right)\end{array}$ & $\begin{array}{c}\text { Luas Tulangan } \\
\left(\mathrm{mm}^{\wedge} 2\right)\end{array}$ & $\begin{array}{c}\text { Mn } \\
(\mathrm{kNm})\end{array}$ & $\begin{array}{c}\text { Mu } \\
(\mathrm{kNm})\end{array}$ \\
\hline 300 & 70714.28571 & 707.1428571 & 1061.858317 & 63.7570988 & 41.442114 \\
400 & 125714.2857 & 1257.142857 & 1608.495439 & 152.404296 & 99.062792 \\
500 & 196428.5714 & 1964.285714 & 2268.229896 & 296.92506 & 193.00129 \\
600 & 282857.1429 & 2828.571429 & 3041.061689 & 512.339859 & 333.02091 \\
700 & 385000 & 3850 & 3926.990817 & 808.231124 & 525.35023 \\
800 & 502857.1429 & 5028.571429 & 5284.158843 & 1233.43738 & 801.7343 \\
900 & 636428.5714 & 6364.285714 & 6433.981755 & 1784.66154 & 1136.63 \\
\hline
\end{tabular}


Tabel 2. Perhitungan momen ultimit, jumlah tulangan 6, f'c 22.5 Mpa

\begin{tabular}{cccccc}
\hline $\begin{array}{c}\text { Diameter } \\
(\mathrm{mm})\end{array}$ & $\begin{array}{c}\text { Luas Penampang } \\
\left(\mathrm{mm}^{\wedge} 2\right)\end{array}$ & $\begin{array}{c}0.01 \mathrm{Ag} \\
\left(\mathrm{mm}^{\wedge} 2\right)\end{array}$ & $\begin{array}{c}\text { Luas Tulangan } \\
\left(\mathrm{mm}^{\wedge} 2\right)\end{array}$ & $\begin{array}{c}\mathrm{Mn} \\
(\mathrm{kNm})\end{array}$ & $\begin{array}{c}\mathrm{Mu} \\
(\mathrm{kNm})\end{array}$ \\
\hline 300 & 70714.28571 & 707.1429 & 1206.371579 & 75.3238501 & 48.9605 \\
400 & 125714.2857 & 1257.143 & 1701.172422 & 174.165009 & 113.2073 \\
500 & 196428.5714 & 1964.286 & 2280.796267 & 331.491357 & 215.4694 \\
600 & 282857.1429 & 2828.571 & 2945.243113 & 562.776633 & 365.8048 \\
700 & 385000 & 3850 & 3963.119133 & 901.825569 & 586.1866 \\
\hline
\end{tabular}

Tabel 3. Perhitungan momen ultimit, jumlah tulangan 4, f'c $22.5 \mathrm{Mpa}$

\begin{tabular}{cccccc}
\hline $\begin{array}{c}\text { Diameter } \\
(\mathrm{mm})\end{array}$ & $\begin{array}{c}\text { Luas Penampang } \\
\left(\mathrm{mm}^{\wedge} 2\right)\end{array}$ & $\begin{array}{c}0.01 \mathrm{Ag} \\
\left(\mathrm{mm}^{\wedge} 2\right)\end{array}$ & $\begin{array}{c}\text { Luas Tulangan } \\
\left(\mathrm{mm}^{\wedge}\right)\end{array}$ & $\begin{array}{c}\text { Mn } \\
(\mathrm{kNm})\end{array}$ & $\begin{array}{c}\mathrm{Mu} \\
(\mathrm{kNm})\end{array}$ \\
\hline 300 & 70714.28571 & 707.1429 & 1206.371579 & 89.28372 & 58.03442 \\
400 & 125714.2857 & 1257.143 & 1701.172422 & 199.6561 & 129.7765 \\
500 & 196428.5714 & 1964.286 & 2280.796267 & 371.1161 & 241.2255 \\
600 & 282857.1429 & 2828.571 & 2945.243113 & 640.0415 & 416.027 \\
700 & 385000 & 3850 & 3963.119133 & 981.1209 & 637.7286 \\
\hline
\end{tabular}

Tabel 4. Perhitungan momen ultimit, jumlah tulangan 8, f'c $25 \mathrm{Mpa}$

\begin{tabular}{cccccc}
\hline $\begin{array}{c}\text { Diameter } \\
(\mathrm{mm})\end{array}$ & $\begin{array}{c}\text { Luas Penampang } \\
\left(\mathrm{mm}^{\wedge} 2\right)\end{array}$ & $\begin{array}{c}0.01 \mathrm{Ag} \\
\left(\mathrm{mm}^{\wedge} 2\right)\end{array}$ & $\begin{array}{c}\text { Luas Tulangan } \\
\left(\mathrm{mm}^{\wedge} 2\right)\end{array}$ & $\begin{array}{c}\text { Mn } \\
(\mathrm{kNm})\end{array}$ & $\begin{array}{c}\mathrm{Mu} \\
(\mathrm{kNm})\end{array}$ \\
\hline 300 & 70714.28571 & 707.1428571 & 1061.858317 & 68.268409 & 44.37446583 \\
400 & 125714.2857 & 1257.142857 & 1608.495439 & 163.273437 & 106.127734 \\
500 & 196428.5714 & 1964.285714 & 2268.229896 & 318.328768 & 206.9136995 \\
600 & 282857.1429 & 2828.571429 & 3041.061689 & 549.504192 & 357.177725 \\
700 & 385000 & 3850 & 3926.990817 & 867.13286 & 563.6363588 \\
800 & 502857.1429 & 5028.571429 & 5284.158843 & 1321.76123 & 859.1447997 \\
900 & 636428.5714 & 6364.285714 & 6433.981755 & 1874.8369 & 1218.643983 \\
\hline
\end{tabular}

Tabel 5. Perhitungan momen ultimit, jumlah tulangan 6, f'c $25 \mathrm{Mpa}$

\begin{tabular}{cccccc}
\hline $\begin{array}{c}\text { Diameter } \\
(\mathrm{mm})\end{array}$ & $\begin{array}{c}\text { Luas Penampang } \\
\left(\mathrm{mm}^{\wedge} 2\right)\end{array}$ & $\begin{array}{c}0.01 \mathrm{Ag} \\
\left(\mathrm{mm}^{\wedge} 2\right)\end{array}$ & $\begin{array}{c}\text { Luas Tulangan } \\
\left(\mathrm{mm}^{\wedge} 2\right)\end{array}$ & $\begin{array}{c}\mathrm{Mn} \\
(\mathrm{kNm})\end{array}$ & $\begin{array}{c}\mathrm{Mu} \\
(\mathrm{kNm})\end{array}$ \\
\hline 300 & 70714.28571 & 707.1429 & 1206.371579 & 79.79589 & 51.86733 \\
400 & 125714.2857 & 1257.143 & 1701.172422 & 184.9645 & 120.227 \\
500 & 196428.5714 & 1964.286 & 2280.796267 & 352.7875 & 229.3119 \\
600 & 282857.1429 & 2828.571 & 2945.243113 & 599.7878 & 389.8621 \\
700 & 385000 & 3850 & 3963.119133 & 960.4471 & 624.2906 \\
\hline
\end{tabular}

Tabel 6. Perhitungan momen ultimit, jumlah tulangan 4, f'c $25 \mathrm{Mpa}$

\begin{tabular}{cccccc}
\hline $\begin{array}{c}\text { Diameter } \\
(\mathrm{mm})\end{array}$ & $\begin{array}{c}\text { Luas Penampang } \\
\left(\mathrm{mm}^{\wedge} 2\right)\end{array}$ & $\begin{array}{c}0.01 \mathrm{Ag} \\
\left(\mathrm{mm}^{\wedge} 2\right)\end{array}$ & $\begin{array}{c}\text { Luas Tulangan } \\
\left(\mathrm{mm}^{\wedge} 2\right)\end{array}$ & $\begin{array}{c}\text { Mn } \\
(\mathrm{kNm})\end{array}$ & $\begin{array}{c}\mathrm{Mu} \\
(\mathrm{kNm})\end{array}$ \\
\hline 300 & 70714.28571 & 707.1429 & 1206.371579 & 93.70837 & 60.91044 \\
400 & 125714.2857 & 1257.143 & 1701.172422 & 210.3741 & 136.7432 \\
500 & 196428.5714 & 1964.286 & 2280.796267 & 392.289 & 254.9878 \\
600 & 282857.1429 & 2828.571 & 2945.243113 & 676.8181 & 439.9318 \\
700 & 385000 & 3850 & 3963.119133 & 1039.505 & 675.6782 \\
\hline
\end{tabular}


Tabel 7. Perhitungan momen ultimit, jumlah tulangan 8, f’c $30 \mathrm{Mpa}$

\begin{tabular}{cccccc}
\hline $\begin{array}{c}\text { Diameter } \\
(\mathrm{mm})\end{array}$ & $\begin{array}{c}\text { Luas Penampang } \\
\left(\mathrm{mm}^{\wedge} 2\right)\end{array}$ & $\begin{array}{c}0.01 \mathrm{Ag} \\
\left(\mathrm{mm}^{\wedge} 2\right)\end{array}$ & $\begin{array}{c}\text { Luas Tulangan } \\
\left(\mathrm{mm}^{\wedge} 2\right)\end{array}$ & $\begin{array}{c}\text { Mn } \\
(\mathrm{kNm})\end{array}$ & $\begin{array}{c}\mathrm{Mu} \\
(\mathrm{kNm})\end{array}$ \\
\hline 300 & 70714.28571 & 707.142857 & 1061.858317 & 77.3064299 & 50.24917943 \\
400 & 125714.2857 & 1257.14286 & 1608.495439 & 185.045979 & 120.2798863 \\
500 & 196428.5714 & 1964.28571 & 2268.229896 & 361.1999123 & 234.779943 \\
600 & 282857.1429 & 2828.57143 & 3041.061689 & 623.9389677 & 405.560329 \\
700 & 385000 & 3850 & 3926.990817 & 985.1000399 & 640.3150259 \\
800 & 502857.1429 & 5028.57143 & 5284.158843 & 1498.664767 & 974.1320985 \\
900 & 636428.5714 & 6364.28571 & 6433.981755 & 2127.542593 & 1382.902686 \\
\hline
\end{tabular}

Tabel 8. Perhitungan momen ultimit, jumlah tulangan 6, f’c $30 \mathrm{Mpa}$

\begin{tabular}{cccccc}
\hline $\begin{array}{c}\text { Diameter } \\
(\mathrm{mm})\end{array}$ & $\begin{array}{c}\text { Luas Penampang } \\
\left(\mathrm{mm}^{\wedge} 2\right)\end{array}$ & $\begin{array}{c}0.01 \mathrm{Ag} \\
\left(\mathrm{mm}^{\wedge} 2\right)\end{array}$ & $\begin{array}{c}\text { Luas Tulangan } \\
\left(\mathrm{mm}^{\wedge} 2\right)\end{array}$ & $\begin{array}{c}\text { Mn } \\
(\mathrm{kNm})\end{array}$ & $\begin{array}{c}\mathrm{Mu} \\
(\mathrm{kNm})\end{array}$ \\
\hline 300 & 70714.28571 & 707.1429 & 1206.371579 & 88.7633 & 57.69614 \\
400 & 125714.2857 & 1257.143 & 1701.172422 & 206.6119 & 134.2978 \\
500 & 196428.5714 & 1964.286 & 2280.796267 & 395.4653 & 257.0524 \\
600 & 282857.1429 & 2828.571 & 2945.243113 & 673.9473 & 438.0657 \\
700 & 385000 & 3850 & 3963.119133 & 1077.91 & 700.6417 \\
\hline
\end{tabular}

Tabel 9 Perhitungan Momen Ultimit, Jumlah Tulangan 4, f’c $30 \mathrm{Mpa}$

\begin{tabular}{cccccc}
\hline $\begin{array}{c}\text { Diameter } \\
(\mathrm{mm})\end{array}$ & $\begin{array}{c}\text { Luas Penampang } \\
\left(\mathrm{mm}^{\wedge} 2\right)\end{array}$ & $\begin{array}{c}0.01 \mathrm{Ag} \\
\left(\mathrm{mm}^{\wedge} 2\right)\end{array}$ & $\begin{array}{c}\text { Luas Tulangan } \\
\left(\mathrm{mm}^{\wedge} 2\right)\end{array}$ & $\begin{array}{c}\text { Mn } \\
(\mathrm{kNm})\end{array}$ & $\begin{array}{c}\mathrm{Mu} \\
(\mathrm{kNm})\end{array}$ \\
\hline 300 & 70714.28571 & 707.1429 & 1206.371579 & 102.5906 & 66.68386 \\
400 & 125714.2857 & 1257.143 & 1701.172422 & 231.8749 & 150.7187 \\
500 & 196428.5714 & 1964.286 & 2280.796267 & 434.745 & 282.5843 \\
600 & 282857.1429 & 2828.571 & 2945.243113 & 750.5558 & 487.8613 \\
700 & 385000 & 3850 & 3963.119133 & 1156.541 & 751.7518 \\
\hline
\end{tabular}

\section{Grafik analisa penampang}

Dari hasil perhitungan Analisa penampang, maka bisa didapatkan grafik yang menunjukkan momen ultimit yang dapat ditahan oleh tiang bor yang memiliki berbagai macam diameter.

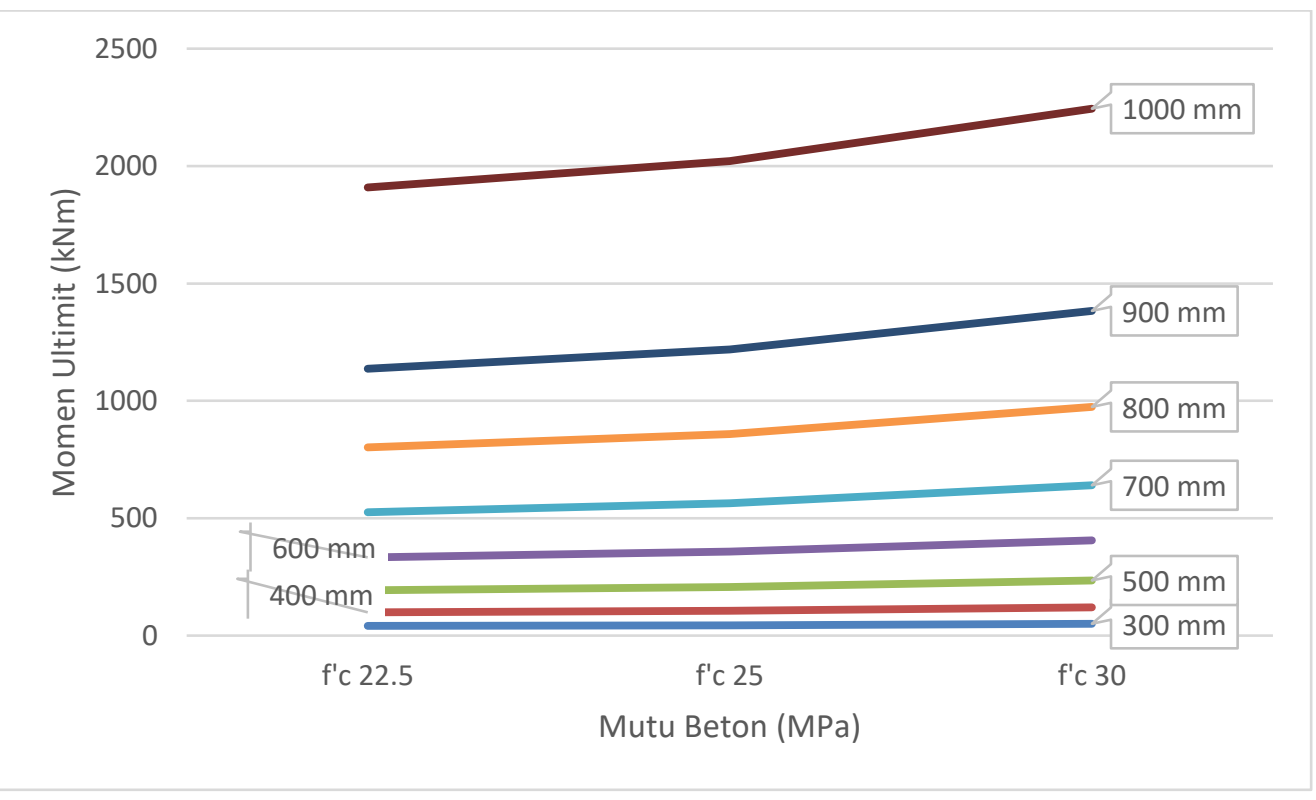

Gambar 6. Perbandiingan nilai Mu dengan mutu beton tulangan 8 


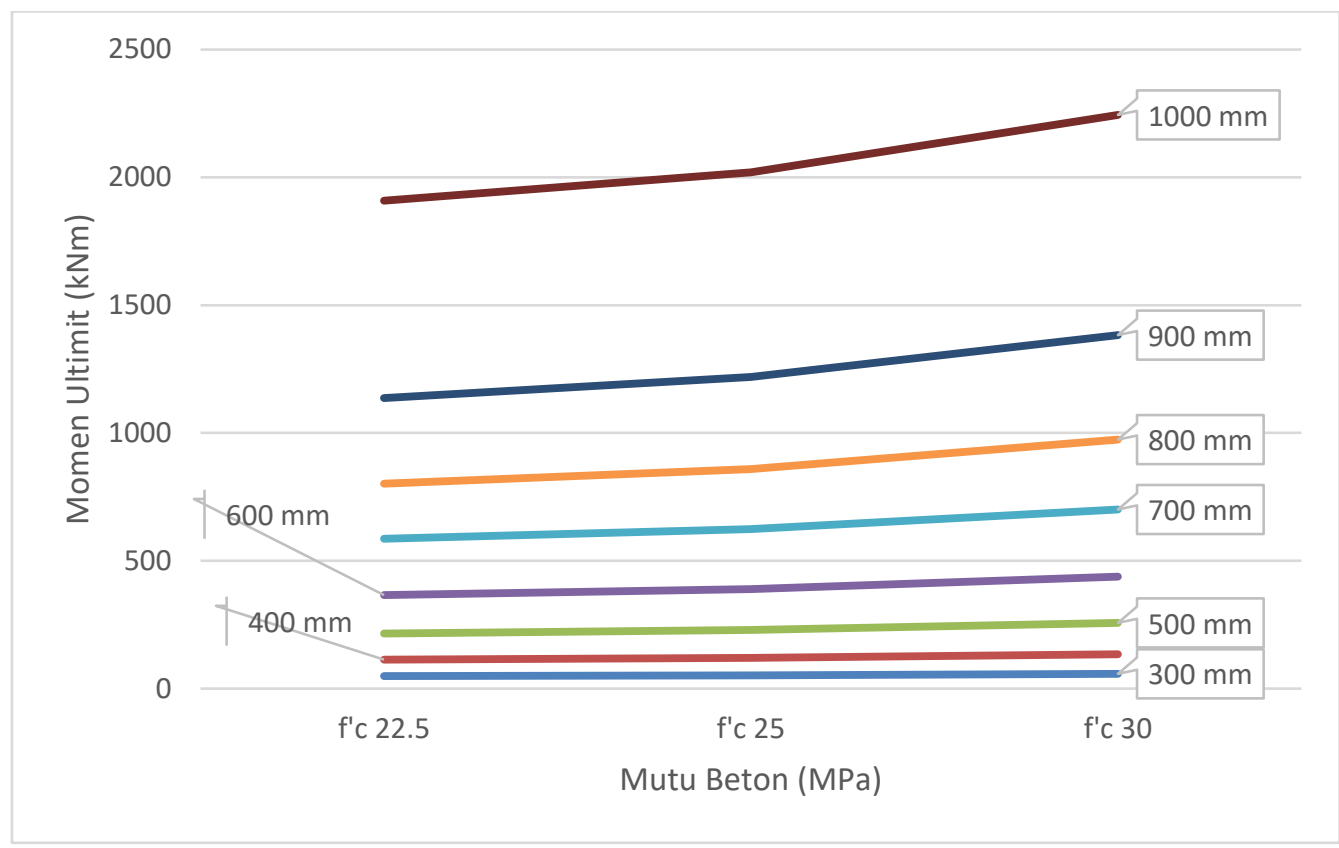

Gambar 7. Perbandingan nilai Mu dengan mutu beton tulangan 6

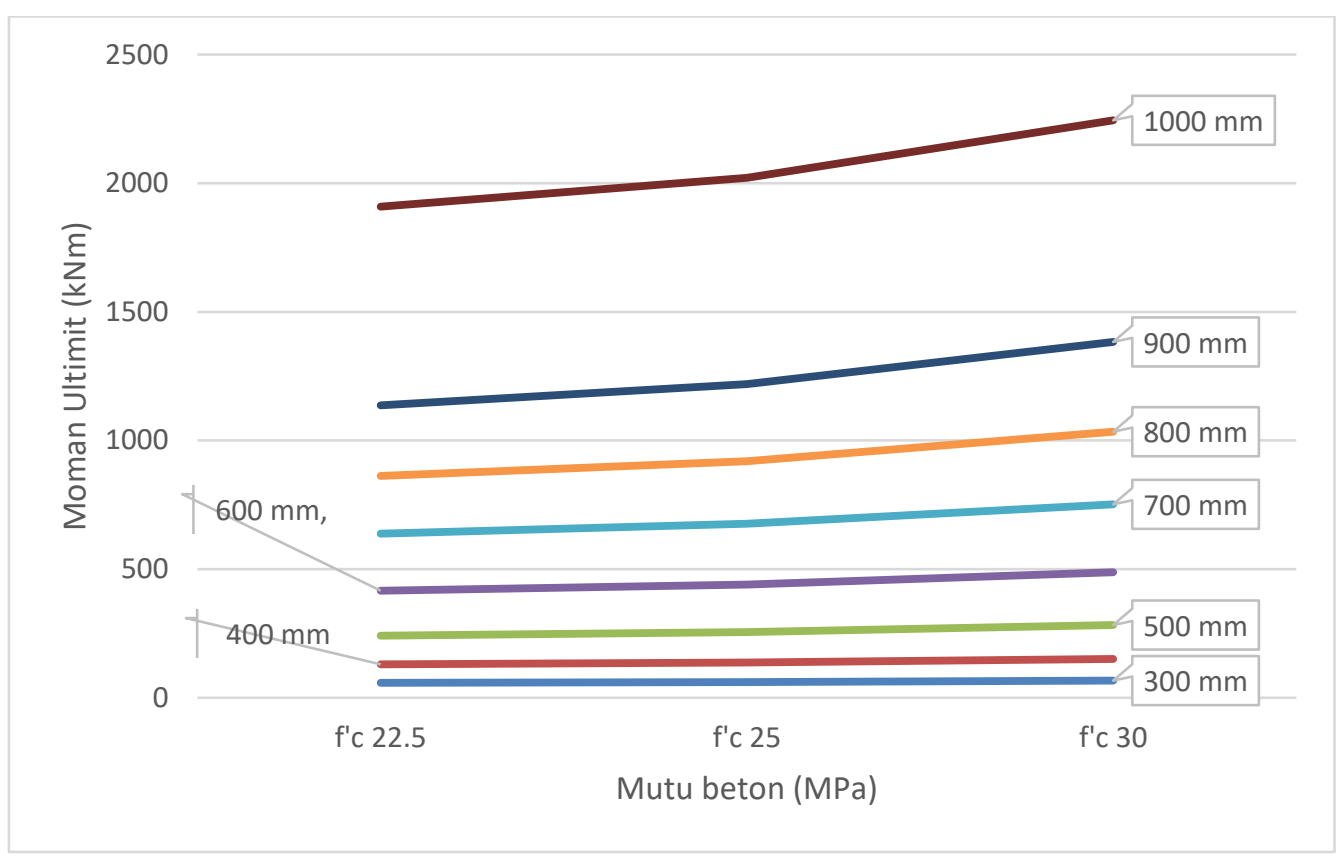

Gambar 8. Perbandingan nilai Mu dengan mutu beton tulangan 4

Dari hasil grafik, diketahui bahwa dengan menggunakan mutu beton yang berbeda, maka nilai momen ultimit yang didapatkan pun juga berbeda, mutu beton $30 \mathrm{Mpa}$ mempunyai nilai momen ultimit yang lebih besar jika dibandingkan denga mutu beton lainnya. Selain itu dengan meggunakan tulangan yang berjumlah 8 , rasio kenaikannya akan lebih konstan berkisar antara 21\%, jika dibandingkan dengan jumlah tulangan lainnya. Kekuatan momen tiang bor lebih kecil dibandingkan dengan tiang pancang, karena tiang pancang dengan ukuran diameter yang sama dan jumlah tulangan yang sama, momen ultimitnya jauh lebih besar. 


\section{KESIMPULAN DAN SARAN}

\section{Kesimpulan}

1. Kenaikan rasio kekuatan momen ultimit sebesar $21 \%$ untuk jumlah tulangan 8 , dimana kenaikannya sangat konstan, sedangkan untuk jumlah tulangan 6 kenaikannya berkisar antara 17\%-21\%, begitu juga untuk jumlah tulangan 4, kenaikannya hanya berkisar antar 14\%-17\%.

2. Dari hasil perbandingan dengan tiang pancang yang didapat dari brosur dengan memiliki diameter sama (500 $\mathrm{mm})$, kekuatan tiang pancang lebih kuat daripada kekutan tiang bor.

3. Tiang bor yang memliki jumlah tulangan 8 lebih kuat, karena selain bisa menahan beban besar, kenaikan kekuatan juga konstan yaitu $21 \%$, sehingga tidak susah untuk mencari diameter tulangan yang akan dipakai.

4. Dengan diameter $300 \mathrm{~mm}$ dan $400 \mathrm{~mm}$ serta mutu beton $22.5 \mathrm{Mpa}, 25 \mathrm{Mpa}$, dan $30 \mathrm{Mpa}$, kenaikan kekuatan tidak jauh berbeda.

5. Momen Nominal Penampang yang bekerja cukup besar dibandingkan momen kerja yang terjadi akibat beban ijin, sehingga penampang aman.

\section{Saran}

Berdasarkan hasil analisis yang telah dilakukan, saran yang dapat disampaikan yaitu sebaiknya dilakukan penelitian yang lebih mendetail, karena dalam skripsi ini hanya menghitung analisa penampang lingkaran saja.

\section{DAFTAR PUSTAKA}

ACI Committee 340. ACI Design Handbook: Design of Structural Reinforced Concrete Elements in Accordance with the Strength Design Method of ACI 318 - 95. Publication SP - 17, 1997.

Badan Standardisasi Nasional. SNI 2847-2013: Persyaratan Beton Struktural Untuk Bangunan Gedung. Badan Standardisasi Nasional, 2013.

Dipohusodo, I. Struktur Beton Bertulang. Gramedia Pustaka Utama, 1999.

Hardiyatmo, Hary Christady. Analisis dan Perancangan Fondasi. Vol.1, Gadjah Mada University Press, 2010.

Kamus Besar Bahasa Indonesia, 2008.

Ridwan, M. Buku Ajar Struktur Beton Bertulang I dan II. Institut Teknologi Padang, 2012.

Setiawan, Agus. Perencanaan Struktur Beton Bertulang. Erlangga, 2017.

Tomlinson M.J. Pile Design and Construction Practice. 4th Ed., E \& FN Spon, 1984.

Wahyudi, L. dan Syahril A. Rahim. Struktur Beton Bertulang (Standar Baru SNI T-15-1991-03). Gramedia Pustaka Utama, 1997.

Wang, Chu-Kia. Disain Beton Bertulang. Jilid 1, Erlangga, 1987. 
Analisis Momen Nominal Tiang Bor untuk Digunakan pada

Reynard Julio Widjaja, et al.

Perhitungan Metode Broms 